\title{
Felicity Conditions of the Speech Acts in Banyumasan Daily Conversation
}

\author{
Chusni Hadiati \\ English Department, Faculty of Humanities, Jenderal Soedirman University, Indonesia
}

\begin{abstract}
A truth conditional sentence requires a sentence to fit into the world; however, it cannot be applied pragmatically in a daily conversation, consequently, non-truth conditional sentence is applied. In pragmatics filed, an utterance needs to be felicitous, thus it has to meet the felicity condition. Felicity condition underlies that in order to be felicitous an utterance must meet the felicity condition that includes preparatory condition, propositional content, sincerity condition, and essential condition. By using felicity condition, speakers can mean what they say and say what they mean. Searle has only postulated the felicity condition for directive and commisives, thus this article attempts to complete the felicity conditions of another three speech acts. The utterances are taken from Banyumas dialect or Banyumasan; it is a dialect of standard Javanese spoken along Serayu River. It has unique characteristic due to its phonological and lexical items compared to Standard Javanese spoken in Yogyakarta and Surakarta. This article describes the felicity condition of the speech acts found in Banyumasan daily conversation which is conducted by using descriptive analysis. The finding of this research shows that felicity conditions of Banyumasan are realized into representative, directives, commisives, expressive, and declarations.
\end{abstract}

Index Terms - utterance, felicity conditions, speech acts, Banyumas dialect, conversation

\section{INTRODUCTION}

Speech acts have been the heart of pragmatic studies for decades, however, only few researches have been produced in term of felicity condition. Researches on pragmatics usually concern about the classification of speech acts and little did researchers discussed on felicity condition of an utterance. Felicity condition is essential in pragmatics studies since it tries to provide sufficient explanation of utterance that cannot be explained by using truth conditional semantics. An utterance cannot be said as true or false only by considering whether or not it fits the world. An utterance will be felicitous only if it fulfills the conditions. A promise will be felicitous if the one who makes it fulfills it in the future time, as a consequence, a promise cannot be made in the past time. "I would come to your house' is not a promise since it is produced in the past time; therefore, the right utterance for a promise is 'I will come to your house'. The use of verb 'would' instead of 'will' does not meet the condition of a promise because the propositional content in which a speaker predicates a future act is not fulfilled. Considering some conditions of an utterance will lead speaker and hearer to produce felicitous utterances.

This article tries to reveal the felicity condition of utterances in Banyumas dialect. Koentjaraningrat (1990) states that Banyumas dialect is a dialect of Javanese language which is spoken along Serayu River (p.23). Banyumasan is somehow different from standard Javanese due to its phonological and lexical features (Wedhawati, 2006, p. 17). Relate to its unique phonological and lexical features, Banyumasan is also widely known as Ngapak-Ngapak (Herusatoto, 2008, p. 122). A lot of researches on Banyumas dialect have been conducted on certain kinds of topics such as language maintenance (Wijana, 2005), implicature (Hadiati, 2014), and intensifiers (Hadiati, 2017), however, little has discussed the felicity condition of utterance. Felicity condition becomes essential in conversation because whether or not speakers mean what they say and say what they mean can be pragmatically inferred through it.

This study belongs to descriptive qualitative research since it tries to reveal language phenomena which are qualitatively described in words instead of number. The research is bounded by time and the processes of data collection are also conducted during a continuous period of time (Creswell, 1994). Data are gathered from daily conversation in Banyumas dialect in which I as a researcher is actively and passively involved. To generate an utterance, I initiate the conversation or simply contribute to the conversation that is happening. The produced utterances are then noted and analyzed in order to formulate the felicity condition that covers preparatory condition, propositional content, sincerity condition, and essential condition. Data are collected from natural communication in Banyumas dialect. Natural data is preferable in qualitative research since it shows real social praxis of language use in society. This research also tries to complete the formula of felicity condition proposed by Searle (1970). Thus, it will add novelty to the study of pragmatics, precisely the felicity condition of utterances.

Felicity condition was initially postulated by Austin, in which he stated that an utterance was not merely an utterance; a speaker does something through the utterance. By uttering it, a speaker acts something as well; and it is widely known today as a speech act. How to Do Things with Words (1962) written by Austin has several excellences as follows. Firstly, it overcomes those that cannot be handled by using truth conditional sentence; secondly, Austin's work is more 
understandable and more accessible compared to other philosophical work at that time; thirdly, it has high consistency since Austin develops his theory in quite a long period; fourthly, it gives umbrella to the study of today's pragmatic analysis.

Thomas (1995) explains that in line with truth conditional semantics, an utterance will be meaningful if it fits with the world, the truth that can be proven in real world (p. 30). If the utterance does not fit the real world, it can be said as truth. She further adds that an utterance like "An invisible car came out of nowhere, hit my car and vanished" cannot fits the world because 'a car cannot be invisible', it must be visible; 'came out of nowhere' is nonsense because the word 'came or come' is used to express where a thing comes from. Thus, based on truth conditional sentence, an utterance like 'An invisible car came out of nowhere, hit my car and vanished' does not meet the truth.

To overcome the deadlock of truth conditional semantics, Austin proposes felicity condition. He elaborates that an utterance cannot be said as true or false, it can only be measured by using some conditions, if an utterance meets those conditions, it must be felicitous. Austin in Levinson (1995, p. 229) states that an utterance at least has to fulfill the three conditions as follows.

A. (i) There must be a conventional procedure having a conventional effect.

(ii) The circumstances and persons must be appropriate, as specified in the procedure.

B. The procedure must be executed (i) correctly and (ii) completely.

C. Often (i) the person must have the requisite thoughts, feelings and intention, as specified in the procedure, and (ii) if consequent conduct is specified, then the relevant parties must so do.

Those three conditions are then further developed by his student, Searle, who introduces four conditions in order for an utterance to be felicitous; those are preparatory condition, propositional content, sincerity condition, and essential condition (1970). Preparatory condition is a conventional procedure of the utterance, i.e. a speaker is able to perform an utterance and that he or she is not under control of other's power. He or she is willing to perform an utterance. A speaker who utters a promise will fulfill the preparatory condition if he or she is able to utter that promise and that he or she is not under control of other's power. Propositional content is a circumstance in which an utterance is produced. The condition when an utterance is uttered will give a clue whether or not an utterance is felicitous. To mention a few, a promise cannot be made for the sake of past time due to the fact that a promise can only be made for the future time. Sincerity condition is a condition in which the speaker is sincere in committing what he or she has been uttered. A speaker who makes a promise must be sincere to keep the promise in order to fulfill the sincerity condition. Last but not least is essential condition which clearly states that a speaker intends to act as it can be seen from the utterance and that he or she is also able to perform it. A promise will be a promise if the speaker really intends to keep it and perform it.

There are five types of speech acts, namely, representatives, expressives, directives, commisives, and declaration; however, in some literatures, Searle has only mentioned felicity conditions of directive and commisives (Searle, 1970; Renkema, 2004). He has not listed the felicity conditions of representatives, declarations, and expressives. There is a slight difference between felicity condition proposed by Austin and those proposed by Searle. In Austin's felicity condition, the role of participants and the context must be acknowledged by all parties; the action must be conducted completely, and the doer must have the right intentions of doing that thing. The general condition in Searle's for all speech acts, the speaker must not be pretending and the hearer must hear and understand the language. It will be infelicitous if the hearer cannot understand speakers' utterances. This study tries to seek the felicity conditions of those five speech acts as they are used in Banyumasan daily conversation. This dialect which is spoken in Banyumas regency, Purbalingga regency, Banjarnegara regency, Cilacap regency and Kebumen is grouped into Proto Austronesian language (Wedhawati et al, 2006, p. 9).

Context is a compulsory part in analyzing utterance in pragmatic scope since it helps speakers to achieve the aims of conversation. It is broadly defined as any circumstances that encompass a text both spoken and written text. It can be, for example, who the speakers are, where the conversation happens, what the topics of the conversations are, and how it is delivered. Relate to the context of language use, language function is basically divided into two categories, as referential function and affective function. When language carries referential information, it belongs to referential function and when it is used to express personal feeling, it is classified as affective function (Holmes, 2001, p. 10). Context is essential in calculating the felicity conditions of speech acts since it will provide information for the propositional content of the felicity condition.

\section{The Felicity CONDITION OF REPRESENTATIVES in BANYumas DialeCt}

Millions of utterances are produced on daily basis. An utterance that shows speakers' understanding about the world can be categorized as representatives. Utterances to state, to announce, to claim, to describe, to insist, and to predict are examples of representatives which are commonly found in daily conversation. Utterance (1) in the conversation below shows what a speaker believes to be true.

Context: $\quad$ A mother and a daughter are in the kitchen, preparing the meal. She explains to her daughter about the peanuts they are going to use in their recipe.

Daughter: $\quad$ Niki kacange sae temen ma. (The peanuts are superb Mom)

Mother: $\quad$ Kiye jenenge kacang Jawa, lewih maen timbang kacang India. (It is Javanese peanut (Arachis hypogaea), it is better than Indian peanut. 
Utterance (1) Kiye jenenge kacang Jawa, lewih maen timbang kacang India is an example of representatives since it describes speaker's understanding on certain matter. The speaker believes what she says is true due to her knowledge. This utterance fulfills the felicity condition of representatives. The preparatory condition of utterance (1) is the fact that the speaker is able to produce the utterance. The speaker can pronounce the utterance clearly so that it can be clearly heard by the hearer and she is not under other people's control in producing her utterance. By uttering (1), the speaker informs the hearer the thing that is mentioned in her utterance. Thus this utterance fits the preparatory condition.

The propositional content of utterance (1) can be seen from the context. Utterance (1) is produced as a reply to the previous utterance that compliments the product quality. The speaker answers the compliment by stating utterance (1). If she says, for example, 'it is none of your business' the utterance will not fulfill the propositional content since it does not answer the previous statement. By producing utterance (1), speaker accomplishes the propositional content of representatives.

Sincerity condition of representatives shows that the speaker is really sincere in committing her utterance. When the speaker produces utterance (1) she is sincere that the good (Javanese peanut) is better than (Indian peanut) due to her knowledge. As far as the speaker's knowledge is concerned, Javanese peanuts are smaller in size compared to Indian peanuts; however, the former are tastier than the later. Speaker knows exactly that the quality of Javanese peanuts is better than Indian peanuts. Thus, utterance (1) completes the sincerity condition. From the context of the conversation, this conversation happens between a mother and her daughter in which the mother really wants to educate her daughter and giving genuine information will be more appreciated than the fake one.

Essential condition of utterance (1) is shown by the intention of the speaker in uttering (1). By performing (1), the speaker really wants to give information about the quality of the goods to the hearer. The intention of giving information as it is mentioned in the utterance clearly shown by the speaker in which she tries to give the genuine information. By telling the genuine information, the speaker really intends to perform 'giving information' to the hearer. Consequently, utterance (1) fits the essential condition of representatives.

Relating the felicity condition of utterance (1) with the context, it can be seen that utterance (1) is felicitous since it happens between a mother and a daughter where the mother tries to educate her daughter by giving genuine information as informative as she can obtain the knowledge about the goods. Utterance (1) belongs to referential function because it has referential content that is giving information on certain thing.

\section{The FELICITy CONDITION OF EXPRESSIVES IN BANYUMAS DiALECT}

Expressive is meant to give evaluation on certain matter as it is mentioned in the utterance. It can also be used by a speaker to express what she has inside his mind, in a simple way, it can be said that expressive speech acts show strong interpersonal function in communication. A compliment, a condoling expression, and a regretting expression are the examples of expressive speech acts. Utterance (2) in the conversation below depicts a compliment.

Context: $\quad$ A mother and a aughter are in the kitchen, preparing the meal. She explains to her daughter about the peanuts they are going to use in their recipe.

Daughter: Niki kacange sae temen ma. (The peanuts are superb Mom)

Mother: Kiye jenenge kacang Jawa, lewih maen timbang kacang India. (It is Javanese peanut (Arachishypogaea), it is better than Indian peanut.

Utterance (2) Niki kacange sae temen ma is an example of expressive speech act since it shows speaker evaluation on certain thing as it can be found in the utterance. She admires the quality of the goods. The preparatory condition of utterance (2) is that the speaker wants to express her feeling/evaluation on certain thing as it is stated in the utterance. She is able to utter the utterance in which she has the capability to produce the linguistic units so that the hearer can clearly catch the utterance. In addition, speaker is free and not under other's pressure to utter it. In accordance to that condition, utterance (2) fits the preparatory condition of expressive speech act.

Propositional content is a circumstance in which an utterance is produced. Utterance (2) comply the propositional content since the circumstance support the production of the utterance. After seeing the goods, the speaker feels that the goods have superb quality so she produces utterance (2). In case she produces contrary expression, 'the peanuts are so poor', she may have other intention and it can be concluded that utterance 'the peanuts are so poor' does not meet the propositional content. Since the circumstance support the production of utterance (2), it is clear that utterance (2) fits the propositional content.

Sincerity condition of utterance (2) is proven when the speaker sees the goods and she is sure that the goods have superb quality. From her perception, the speaker can see that Javanese peanuts are superb so that she has the evidence to produce utterance (2). What she sees trigger the emergence of utterance (2) so that utterance (2) can be categorized as a sincere statement and it has physical evidence. If, the speaker for example says 'the peanuts are so poor', her utterance is not supported by the evidence; consequently, utterance 'the peanuts are so poor' is infelicitous and utterance (2) is felicitous.

Utterance (2) also meets the requirement of essential condition since it is meant to show compliment on a certain thing or to show speaker's evaluation. In the context that the goods have superb quality, it will be infelicitous if the speaker states the contrary. Knowing the quality of the goods, the speaker then produces utterance (2) which is a 
compliment that is supported by the physical evidence. By combining the physical evidence and the linguistic realization, it can be inferred that utterance (1) meets the essential condition.

Utterance (2) fulfills the preparatory condition, propositional content, sincerity condition, and essential condition so that utterance (2) is felicitous. Giving compliment is a kind of expressive speech act and it will be felicitous if the compliment is also supported by the evidence provided by the context of communication. Since expressive is used by the speaker to give evaluation, this speech act is closely related to interpersonal function of language. Interpersonal functions are commonly used to give lubrication in human interaction.

\section{The Felicity Condition of DiReCtives in Banyumas Dialect}

Directives can be said as essentially command, it is a speech act that describes how a speaker gives command to the hearer. Commands can be in the form of requesting, inviting, forbidding, suggesting, and so on. Utterance (3) Undangna bapake nganah, kiye ana laying penting in the conversation below shows the realization of directives in Banyumas dialect.

Context: A man comes to his neighbor house to deliver a message. He unfortunately cannot meet the house owner and he just meets his neighbor's daughter so that he asks her to call his father.

A man: $\quad$ Undangna bapake nganah, kiye ana laying penting. (Call your father here it is an important letter)

A girl: $\quad$ Nggih pak gedhe. (Yes sir).

Utterance (3) Undangna bapake nganah, kiye ana laying penting is an example of directives since it is aimed at making the hearer do something, in the context above, the speaker wants hearer to call her father. The preparatory condition of utterance (3) is that the speaker is able to utter the utterance the hearer is able to catch the utterance clearly. The speaker is also free to produce his utterance and he is not under control of other. In a simple way, it can be said that the speaker is able to pronounce Undangna bapake nganah, kiye ana laying penting. The speaker is older than the hearer so it makes sense when he utters his utterance in Ngoko. Ngoko is a language variation in Javanese Language which is commonly spoken from older speakers to younger speakers.

Propositional content is a circumstance in which an utterance is produced. Utterance (3) fits the propositional content since the circumstance support the production of the utterance. After knowing that the speaker cannot meet the neighbor he wants to meet and he only meets his neighbor's daughter, he then produces utterance (3). Utterance (3) shows that the speaker commands his hearer to do something as it is stated in the utterance. He commands her to call her father. Utterance (3) fits the propositional content since the circumstance allows this utterance to occur. In addition, speaker also predicts that the hearer can perform a future action, for example, calling her father. By calculating that the hearer can perform a future action as it is mentioned in the utterance, utterance (3) completes the propositional content.

Sincerity condition of utterance (3) is proven when the speaker does not see the person he wants to meet and he knows exactly that that person's daughter (the one he meets) can do his request as it is stated in utterance (3). The speaker knows that that girl is the daughter of the man he wants to meet consequently it is very possible for that daughter to call her father and inform him that there is a guest waiting for him. The speaker also very sure that that girl is willing to do what he wants. Based on the speaker schemata, he knows that the hearer can do what he wants and the speaker wants the hearer to do what he request. In other word, utterance (3) fulfills the sincerity condition of a directive speech act.

Uttering utterance (3) is counted as speaker's effort to make the hearer does something as it is mentioned in the utterance. By producing utterance (3) the speaker wants the hearer to call her father and inform him that there is a guest for him. An attempt committed by the speaker to make the hearer to do something belongs to the essential condition of a directive speech act.

Since utterance (3) completes the preparatory condition, propositional content, sincerity condition, and essential condition, it can be classified as a felicitous speech act. Giving command is a directive speech act since in that speech act speaker ask the hearer to do something as it is informed in the utterance. Relate to the function of language, directive speech acts belong to referential function since it is used to express referential content rather than interpersonal feelings. In that context, speaker gives command to the hearer to do call her father.

\section{The Felicity Condition of Commissives in BANyumas Dialect}

Commissives are speech acts which commit the speaker to some future course of action. They include promises and their converse, threats; the difference depends on how the hearer will be affected by the proposed act. An example of commissives speech act in Banyumas dialect can be seen in the conversation below.

Context: $\quad$ Speaker discussing something with the hearer and before leaving the hearer, the speaker promises to the hearer that he will deliver something to the hearer at four o'clock tomorrow's afternoon.

Speaker: $\quad$ Ngesuk aku njujugnane jam papat sore ya, nek ora udan. (I will deliver the goods at four o'clock tomorrow's afternoon)

Hearer: $\quad$ Ya sesempate bae (OK, anytime will be convenience)

Utterance (4) Ngesuk aku njujugnane jam papat sore ya, nek ora udan is an example of commissives since it describes speaker's future course of action. Speaker ties himself to hearer of certain kind of act in the future as it is 
mentioned in the utterances. In utterance (4), the speaker promises to deliver the goods to the hearer in the future time. This utterance fulfills the felicity condition of commissives because the speaker is able to perform the utterance which means that he can produce the utterance clearly and so does the hearer. In addition to that action, the speaker is also willing to perform the action as it is mentioned in the utterance. Thus, since the speaker can produce the utterance clearly and he is also willing to do it, this utterance fulfills the preparatory condition of a promise.

The propositional content of utterance (4) can be seen from the context because the circumstance of the utterance will enable speaker to complete his utterance. A speaker is healthy and he feels that he can go to hearer's place the next afternoon. If the speaker is not healthy, he may not be able to come to hearer's house the next morning and therefore he cannot perform his promise. If he cannot perform his promise than the utterance (4) will be infelicitous. Since the speaker is healthy and he is able to fulfill his promise, utterance (4) fits the propositional content of a promise.

The sincerity condition of commissives is shown by the intention of speaker to perform his utterance. The speaker is sincere in terms of he is capable of doing the act as stated in his utterance. He is sincere to come to hearer's house the next afternoon to deliver the goods. He is sincere because he knows that he will be free at that time so that he has a chance to come by to the hearer's house. Since the speaker is sincere that he can perform the act by uttering (4), utterance (4) is considered as felicitous speech act of a promise.

The essential condition of utterance (4) is counted as an attempt to the undertaking by speaker of an obligation to do the action as it is stated in the utterance. By uttering (4), the speaker has the obligation to deliver the things to hearer's house in the next afternoon. Utterance (4) will be felicitous if the speaker does come to the hearer's house the next afternoon to deliver the goods. If the speaker does not come to the hearer's house the next afternoon to deliver the goods, utterance (4) will be infelicitous.

Relate to the felicity condition of utterance (4) with the context, it can be inferred that utterance (4) is felicitous due to the fact that it fulfills the preparatory condition, propositional content, sincerity condition, and essential condition. Promise is classified as commisives and it carries referential content, therefore it belongs to referential function.

\section{The Felicity Condition of DeClaration in BANYumas DialeCt}

Declarations are unique forms of speech act, in that their successful performance depends upon the status of the speaker, and the precise circumstances surrounding the event. They are institutionalized in a society. Declarations include sacking a worker, performing a marriage, and sentencing a criminal. In daily conversation, declaration can still be found as it is described in the following conversation. In this conversation, a speaker creates a new condition/status that the debt is paid.

Context: A man who has debt to his friend intends to pay his debt so that when he meets his friend he states that

he wants to pay it.

Man: $\quad$ Kiye aku mbayar utangku wingi sing seket ewu ya. (Here I pay my yesterday's debt. I is fifty thousand rupiah, isn't it?)

Woman: $\quad$ Oh iya, dadi lunas ya kang. (Oh Ok, it is paid then).

In the conversation above, the speaker wants to pay his debt to his friend; hence, he utters 'Kiye aku mbayar utangku wingi sing seket ewu ya'. His friends then replies it by producing utterance (5) Oh iya, dadi lunas ya kang. Utterance (5) is produced by the speaker to change the condition, precisely, to state that the debt is paid. To know whether or not utterance (5) is felicitous, it must fulfill the felicity condition. The preparatory condition of utterance (5) is that the speaker is able to perform the utterance clearly and she has the right to produce the utterance. If the speaker cannot produce the utterance clearly, the hearer will not be able to get the information that the debt is paid. If the hearer cannot hear the utterance clearly, the hearer may not understand the intention. Secondly, the speaker also has the right to produce the utterance. Since she has received the payment she has the right to produce utterance (5) and to inform that the debt is paid. Based on the explanation, utterance (5) fulfills the preparatory condition of creating a new condition.

The propositional content of utterance (5) can be traced from its context. The propositional content of utterance (5) is that the speaker knows how much the debt is and she also knows that the hearer has paid as much as the debt. The speaker knows that the debt is fifty thousand rupiahs and she also knows that the hearer has paid as much as fifty thousand rupiah. Knowing the context of the utterance can help the speaker to figure out that the utterance supports the propositional content. Consequently, utterance (5) completes the propositional content as a declaration.

The sincerity condition of utterance (5) can be explained as the fact that the speaker sincerely wants to change the condition. If the speaker just wants to make joke; therefore utterance (5) will be infelicitous. However, since the speaker sincerely wants to create a new status, utterance (5) is felicitous.

The essential condition of utterance (5) is that it is meant to change or create a new condition in which the debt is paid. The speaker creates the hearer's new status from indebted into not indebted. If she does not really want to change the condition, the production of utterance (5) will be infelicitous. By stating utterance (5), the speaker does not only want to inform (representative speech act) but also to create a new status/condition (declaration speech act). If the speaker merely wants to inform without changing or creating a new status, utterance (5) will not be a declaration, it is a representative. Since the speaker creates a new status, then utterance (5) is felicitous.

Relating declaration speech acts to language functions, it can be seen that declarations belong to referential function since this speech act carries referential meaning by changing the condition or status. If it is only used to lubricate the 
social interaction without carrying referential content, it will function affectively.

\section{CONCLUSION}

Speech acts carry either referential or affective meaning and to be able to measure whether the speech act is felicitous or infelicitous, felicity condition is worth considering. Felicity condition includes preparatory condition, propositional content, sincerity condition, and essential condition in which each of them must be completed by an utterance to be felicitous. In case, a requirement is violated, the speech act will be infelicitous. Consequently if the participants in the conversation consider the felicity condition of each speech act, they can genuinely grasp the meaning of the speech act since not all of them can be analyzed merely by referring to the real world. Felicity condition can give evidence whether the speakers say what they mean and mean what they say. Considering the importance of felicity condition in pragmatic studies, felicity condition becomes indispensable in pragmatic studies; therefore, the analysis of felicity condition gives many chances for pragmatic researcher to make a deeper research to get deeper insight of felicity condition by applying various language data.

\section{ACKNOWLEDGMENTS}

I would like to thank to The late Mr. Subandi, the head of education department of Faculty of Humanities of Jenderal Soedirman University for the valuable suggestion and comment.

\section{REFERENCES}

[1] Austin, J.L. (1962). How to Do Things with Words. Oxford New York: Oxford University Press.

[2] Creswell, John W. (1994). Research Design: Qualitative \& Quantitative Approaches. London: SAGE Publications.

[3] Herusatoto, Budiono. (2008). Banyumas: Sejarah, Budaya, Bahasa dan Watak. Yogyakarta: PT LKiS Aksara.

[4] Hadiati. Chusni. (2014). Redefining Cablaka "Banyumasan way of speaking", is it totally explicature? Theory and Practice in Language Studies 4 (10). 2082-2089. http://www.academypublication.com/issues/past/tpls/vol04/10/14.pdf. Retrived March 7 , 2018.

[5] Hadiati. Chusni. (2017). The Realization of Intensifiers in Banyumas Dialect. Journal of Language and Teaching Research 8 (5) 940-947. www.academypublication.com/ojs/index.php/jltr/article/view/jltr0805940947. Retrieved March 7, 2018.

[6] Holmes, Janet. (2001). An Introduction to Sociolinguistics: Second Edition. England: Pearson Education Limited.

[7] Koentjaraningrat. (1990). Manusia dan Kebudayaan di Indonesia. Jakarta: Djambatan.

[8] Levinson. (1995). Pragmatics. Cambridge: Cambridge University Press.

[9] Renkema, Jan. (2004). Discourse Studies: An Introductory Textbook. Philadelphia: John Benjamins Publishing Company.

[10] Searle, J.R. (1970). Speech Act: An Essay in the Philosophy of Language. Cambridge: Cambridge University Press.

[11] Thomas, Jenny. (1995). Meaning in Interaction: An Introduction to Pragmatics. London: Longman Group Limitted.

[12] Wedhawati et.al. (2006). Tata Bahasa Jawa Mutakhir. Edisi Revisi. Yogyakarta: Kanisius.

[13] Wiyana, I Dewa Putu. (2005). Pemertahanan Dialek Banyuams Terhadap Dominasi Dialek Solo-Yogya. Humaniora 17 (2). 154-159.

Chusni Hadiati is a lecturer in English department, Faculty of Humanities, Jenderal Seodirman University. She gained her Ph.D in linguistics in Universitas Indonesia in 2016. Her research interest includes morphology, pragmatics, stylistics, and Banyumas linguistic and culture. 